\title{
Informal International Border Crossing, Refugee and Illegal Migrant Workers: Issue in Travel Medicine
}

\author{
Viroj Wiwanitkit ${ }^{1,2,3^{*}}$ \\ ${ }^{1}$ Hainan Medical University, Hainan, China \\ ${ }^{2}$ Dr DY Patil University, Pune, India \\ ${ }^{3}$ Faculty of Medicine, University of Nis, Nis, Serbia
}

Corresponding Author: Viroj Wiwanitkit, MD, Professor, Wiwanitkit House, Bangkhae, Bangkok, Thailand.

Email:wviroj@yahoo.com

Received September 28, 2017; Accepted October 10, 2017; Online Published November 6, 2017

Citation: Wiwanitkit V. Informal international border crossing, refugee and illegal migrant workers: issue in travel medicine. Int J Travel Med Glob Health. 2018;6(1):34. doi:10.15171/ijtmgh.2018.07.

\section{Dear Editor,}

International borders are important interim areas around the world. The junctional areas between countries are usually where control is required. Travel across international borders means crossing from one into another country, and legal control is usually required. Nevertheless, due to long international lines, informal border crossings are commonly carried out by the local people. Sometimes this can be a big problem in travel medicine. Two groups of people performing informal international border crossings are refugees and illegal migrant workers. There are many reports regarding the health statuses of those who have informally crossed international borders, and this is an interesting issue in travel medicine. ${ }^{1}$

For example, in Indochina, many developing countries share international borders, and informal border crossings are common. In Thailand-Myanmar and Myanmar-China border areas, migrant workers cross from Myanmar to Thailand or China to find employment, and thus, many diseases are carried from Myanmar to Thailand. Tuberculosis and malaria are 2 important imported diseases. ${ }^{2,3}$ At the same time, to escape the continuous fighting, several ethnic minorities cross international borders into Thailand and live in refugee camps. A survey of the health of a refugee usually reveals several health problems. ${ }^{4}$ The lack of infrastructure and poverty are common, and this might lead to the outbreak of disease. There are also other important health-related issues in this area that should be addressed, including illegal drug transportation, illegal prostitution, illegal transportation of cattle, and illegal gambling. Controlling health problems at international borders usually requires collaboration between countries; yet, this is sometimes very difficult in developing countries, especially if there is an unstable political or social status or war in that area. As noted by McMichael and Healy, ${ }^{5}$ "the focus on migrant health among policy makers and partners, present an opportunity to tackle barriers to health service access, extend coverage, and strengthen partnerships in order to improve migrant health." Currently, this is an important requirement for dealing with problems arising from informal international border crossings.

\section{Conflict of Interest Disclosures}

None.

\section{Ethical Approval}

Not applicable.

\section{Funding/Support}

None.

\section{References}

1. Castaneda H, Holmes SM, Madrigal DS, Young ME, Beyeler N, Quesada J. Immigration as a social determinant of health. Annu Rev Public Health. 2015;36:375-392. doi:10.1146/annurevpublhealth-032013-182419.

2. Ditton MJ, Lehane L. Towards realizing the health-related millennium development goals for migrants from Burma in Thailand. J Empir Res Hum Res Ethics. 2009;4(3):37-48. doi:10.1525/jer.2009.4.3.37.

3. Tschirhart N, Sein T, Nosten F, Foster AM. Migrant and Refugee Patient Perspectives on Travel and Tuberculosis along the Thailand-Myanmar Border: A Qualitative Study. PLoS One. 2016;11(8):e0160222. doi:10.1371/journal.pone.0160222.

4. Srikanok S, Parker DM, Parker AL, et al. Empirical lessons regarding contraception in a protracted refugee setting: A descriptive study from Maela camp on the Thai-Myanmar border 1996-2015. PLoS One. 2017;12(2):e0172007. doi:10.1371/journal.pone.0172007.

5. McMichael C, Healy J. Health equity and migrants in the Greater Mekong Subregion. Glob Health Action. 2017;10(1):1271594. doi:10.1080/16549716.2017.1271594. 